\title{
Research of the Effect of the Cooperative Learning in Vocational High School English Education
}

\author{
Xie Ai-min \\ Jiangxi University of Technology
}

\begin{abstract}
Cooperative learning is a teaching form which takes students as center and group activities as base. Through the way of cooperation, the teaching form promotes learning strategy system. Cooperative learning is practical and creative teaching strategies which is widely used in many countries currently. At present, cooperative learning has become the effective teaching organization of European and American countries, because it can improve the classroom atmosphere, improve students' abilities of using language and enhance students' self-confidence. Through questionnaire survey, after understanding the situation of cooperative learning strategy used in English teaching of vocational high school, this paper points out the existing problems and analyzes the reasons, on the basis of which, it also explores the effective strategies on the implementation of cooperative learning.
\end{abstract}

Keywords-Vocational high school English, English teaching, Cooperative learning

\section{INTRODUCTION}

In recent years, experts and scholars in the field of English teaching in China have been busy on the research of the reform of the traditional English teaching model, constantly trying to combine mastering language knowledge and cultivating communicative ability effectively and made remarkable achievements. In recent years, a new type of teaching mode slowly passed to domestic and from abroad and has brought a big shock to domestic English classroom teaching. It is "cooperative learning" which has practical and creative and has been widely used in many countries. As one of the mainstream teaching strategies in English classroom teaching in many foreign countries, cooperative teaching is widely used in English classroom teaching, and has great effects in improving classroom atmosphere, improving learners'

\author{
Dai Jian-qiang \\ Jiangxi University of Technology
}

performance, cultivating learners' consciousness of lifelong learning and enhancing learners' team-working spirit. However, the English classroom teaching of most of the current domestic vocational high schools is still in the traditional teaching pattern that "teacher speaks, students listen", which has the following disadvantages: Content is boring, the evaluation of learners during teaching is singly without independent inquiry and the time and opportunities of learning, etc.

The aim of this study is to discuss the effective implementation strategies of cooperative learning in English teaching of vocational high school, through the analysis of the problems of cooperative learning in English teaching if vocational high school, and to provide some feasible methods for the English teaching of the vocational high schools with low quality for students.

\section{THE RESEARCH PURPOSE AND MEANING OF COOPERATIVE LEARNING}

Cooperative learning does not only help teachers to teach students according to their aptitude, but also can make up the disadvantage that teachers cannot face learners with different situations, which really makes each student get development goals, enriches learner's learning life and promotes the comprehensive development of learners. In the English teaching of vocational high school, class teaching system is still the main form of English classroom teaching. Cooperative learning's application in vocational high English teaching will bring some benefits for both students and teachers, which shows in:

Make the learners' abilities innovate. Open cooperation classroom teaching can make learners acquire knowledge and skills through a variety of ways and comprehensively use them in practice, thus increase their 
ability to innovate.

Make learners' cooperation consciousness grow. Cooperative learning contains many kinds of communication forms, which can make learner groups establish relationship of mutual cooperation and make learners understand the necessity of cooperation.

Put forward higher requirements for teachers' professional quality and ability. In order to make the effective implementation of cooperative learning, teachers need to fully understand learning information of learners with different levels and timely adjust teaching strategies.

Make English teachers' teaching quality enhance unceasingly. Through the two-way feedback mode of information exchange between teachers and students, teachers shall give inspiration and guidance in view of the problems arising from the cognitive process, to make learners learn smoothly and to achieve the teaching goal.

\section{THE THEORETICAL BASIS OF COOPERATIVE} LEARNING

\section{A. Cognitive theory:}

Lev Vygotsky, the famous psychologist of former Soviet union, pointed out that the problems which cannot be solved by learners themselves independently in their developing stage can be solved with the guidance and cooperation of the peers with the same age and with related knowledge.

\section{B. Group dynamics theory:}

The group dynamics theory of Maslow, the famous psychologist of the USA points out that in cooperative learning teaching strategies, different learners in a team can inspire each other, complement each other, realize the the collision of thinking and wisdom, generate new ideas and creatively complete specific learning tasks.

\section{Subject education theory:}

it specially emphasis on the sociality of teaching activities. It is through cooperative learning that learners develop in the process of mutual cooperation and exchanges. The construction of cooperation learning teaching mode pays special attention to provide learners with multiple platforms and opportunities for communication by creating various kinds of cooperative learning activities

\section{Constructivism theory:}

$\mathrm{T}$ he founder of it, Piaget, the psychologist of Switzerland, pointed out that learning is not a process that teachers tell knowledge simply to learners, but learners themselves construct the knowledge. Learners are not simple and passively receiving information, but actively constructing knowledge, which cannot be replaced by others.

\section{EFFECTIVE IMPLEMENTATION STRATEGIES OF} COOPERATIVE LEARNING IN VOCATIONAL HIGH SCHOOL

\section{ENGLISH TEACHING}

\section{A. Select appropriate cooperation opportunity}

To decide the suitable opportunity to apply cooperation learning strategy, the best way is to develop an annual English teaching plan, to find out carefully in advance those units which conform to use cooperative learning strategies. First of all, the selected units shall not be too academic, because the learners who use cooperative learning for the first time tend to pay much attention to the new experience of cooperative learning and have to spend a lot of effort to grasp some related skills. In addition, teachers always want their learners to have a successful start. Secondly, the content of the selected units shall be suitable for cooperative activities.

\section{B. Design effective cooperation tasks}

The difficulty of the task is also one of the important factors influencing the effect of cooperative learning group. Therefore, vocational high school teachers shall make sure the active task has certain challenging in the design of active task. Cooperative learning is a process of constructing knowledge for learners with the necessary information under certain situation, through collaboration, discussion, communication, helping each other. The process of constructing knowledge shall take students' original knowledge and experience as the starting points of teaching activities and take achieving the construction of the current knowledge of learners as the purpose.

\section{Build a cooperative group with reasonable structure}

Group cooperative learning is a process of teaching and learning, communicating knowledge between learners, and the process of showing mutual love and 
communicating emotions. Build a reasonable structure of cooperation group is not only beneficial to cultivate and stimulate students' interests in learning English of vocational high school, but also beneficial for teachers to easily and effectively carry out teaching activities. Before group division, teachers should consider students' performance, ability, attitude and personality, habits, gender and other factors and make reasonable groups division, making the member of each group has advantage complementary, while ensuring the overall strength between each team is the same to make sure the fairness of competition between groups.

\section{CONCLUSION}

In this paper, the results show that the effective application of cooperative learning in vocational high school English teaching does not only improve students' participation in class activities, but also improves their interests, learning motivation and learning abilities in learning English. Cooperative learning organization structure improves the relationship between teachers and students, students and students of vocational high school, makes the students of vocational high school have a more active attitudes towards their school, learning subjects, students and teachers, which effectively promotes the developments of the school. As language teaching, the form of group cooperative learning provides learners with more opportunities to use English, and also has significant effect to improve learners' overall academic performance of English. Since cooperative learning emphasizes help between each learner, it also plays a big role in improving learners' communicative competence of vocational high school.

\section{REFERENCES}

[1] Grabill J T, Hicks T. Multiliteracies Meet Methods: The Case for Digital Writing in English Education[J]. English Education, 2005, 37(4):301-311.

[2] Daly, John A., and A. Hexamer. "Statistical Power in Research in English Education.." Research in the Teaching of English 17.2(1983): 157-164.

[3] Swenson J, Young C A, Mcgrail E, et al. Extending the Conversation: New Technologies, New Literacies, and English Education.[J]. English Education, 2006, 38(4):351-369.

[4] Barnard H C. A History of English Education from 1760[J]. British Journal of Educational Studies, 1961, 10.

[5] Sperling M, Dipardo A. English Education Research and Classroom Practice: New Directions for New Times[J]. Review of Research in Education, 2008, 32(1):62-108.

[6] Morrell E. Critical English Education[J]. English Education, 2005, 37(4):312-312.

[7] Alsup J, Sawyer M. The State of English Education and a Vision for Its Future: A Call to Arms[J]. English Education, 2006, 38(4):278-294.

[8] Chang Y F. Parents' attitudes toward the english education policy in Taiwan[J]. Asia Pacific Education Review, 2008, 9(4):423-435.

[9] Kirkland D E. "The Rose that Grew from Concrete": Postmodern Blackness and New English Education.[J]. English Journal, 2008, 97(5):69-75.

[10] Chadwick P. Shifting alliances : church and state in English education[M]// Cassell, 1997.

[11] Sakita T I. Sexism in Japanese English Education: A Survey of EFL Texts[J]. Women \& Language, 1995, 18.

[12] Machin S, Mcnally S. The Evaluation of English Education Policies[J]. National Institute Economic Review, 2012, 219(1):R15-R25. 